\title{
Kadar Human Leukocyte Antigen-G Serum Pada Abortus Spontan Dan Kehamilan Normal
}

\author{
Levels Of Human Leukocyte Antigen-G Serum In Spontaneous \\ Abortion And Normal Pregnancy
}

\author{
${ }^{1}$ Sarjani Linggi Allo*, ${ }^{2}$ Samrichard Rambulangi ${ }^{3}$ Irfan Idris, ${ }^{1}$ Erni Yetti R, ${ }^{1}$ Zadrak Tombeg, ${ }^{4}$ Anto J. Hadi \\ ${ }^{1,2,3}$ Universitas Hasanuddin Makassar, ${ }^{1 *}$ Akademi Kebidanan Sinar Kasih Toraja ${ }^{4}$ Institut Kesehatan Helvetia Medan \\ *Email Korespondensi: Janikebid08@gmail.com
}

\begin{abstract}
Abstrak
Adanya penolakan terhadap janin oleh sistim imun ibu karena adanya antigen paternal, diduga menjadi salah satu penyebab abortus oleh karena itu adanya humanleukocyte antigen-g (HLA-G) memegang peran toleransi imun semialogenik fetus untuk pemeliharaan kehamilan.Penelitian ini bertujuan untuk mengetahui kadar HLAG-G serum pada kehamilan normal dan Abortus dengan metode ELISA.Desain penelitian ini adalah cros-sectional dengan jumlah sampel 50 yang dibagi dalam 2 kelompok yaitu25 abortus dan 25 kehamilan normal. Pengambilan sampel dilakukan secara concequtivesampling.Data dianalisis menggunakan uji Mann-whitneydan Independent-samples T test. Hasil uji statistik diperoleh rerata kadar HLA-G serum ibu abortus lebih rendah $(276,08 \pm 69 \mathrm{ng} / \mathrm{L})$ dibandingkan dengan hamil normal $(345,30 \pm 73,54 \mathrm{ng} / \mathrm{L})$ dengan nilai $p 0,001<p$ 0,005. Pada usia ibu 20-35 tahun rerata kadar HLAG pada kehamilan normal 357,57 $\pm 71,40$ dan kelompok abortus $274,57 \pm 85,95$ dengan nilai $=p 0,015$ sedangkan pada usia ibu $<20$ dan $>35$ tahun rerata kadar HLA-G kehamilan normal 306,41 $\pm 72,26$ dan kelompok abortus $276,79 \pm 62,68$ dengan nilai $p=0,034$. Umur kehamilan $>14$ minggu pada kelompok hamil normal rerata kadar HLAG $=353,43 \pm 78,17$ dan kelompok abortus HLA-G $=243,60+61,77$ dengan nilai $p=0,003$ sedangkan umur kehamilan 8-14 minggu pada kelompok hamil normal rerata kada HLA-G=328,01 $\pm 63,82$ dan pada kelompok abortus $288,71 \pm 69,22$ dengan nilai $p=0,185$. Paritas 2-3 pada kelompok hamil normal rerata HLA-G=342,87 $\pm 73,42$ dan kelompok abortus rerata HLA-G= 278,35 $\pm 81,25$ dengan nilai $\mathrm{p}=0,051$ sedangkan paritas $1 \&>3$ pada kelompok hamilan normal rerata kadar HLA-G $=350,46 \pm 78,57$ dan kelompok abortus rerata kadar HLA-G $=274,80 \pm 64,14$ dengan nilai $p 0,043$. Berdasarkan hasil analisis disimpulkan bahwa kadar serum HLA-G pada kelompok abortus lebih rendah dibandingkan kelompok hamilan normal.
\end{abstract}

Kata kunci : HLA-G, Abortus, Kehamilan Normal.

\begin{abstract}
Rejection of the fetus due to recognition of paternal antigens by the maternal immune system, is suspected to be a cause of unexplained pregnancy loss.Human Leukocyte Antigen-G (HLA-G) suspected to be a cause of important inflammatory mediators associated with abortion. This research to determine the levels of HLA-G in serum of the normalpregnancy and abortus as well as placental tissue.The design of the study was cross-sectional with the total samples of 50 patients who were devided into 2 groups; 25 abortus and 25 normal pregnancies. The samples were chosen using the consecutive sampling technique. The levels of serum and HLA-G serum were evaluated using ELISA method. The data were analyzed using Mann-Whitney test and the independent sample T-Test.The result of the statistical test revealed that the main value of the level HLA-G serum in abortus mothers was lower $(276,08+69 \mathrm{ng} / \mathrm{L})$ compared to the normal pregnant mothers $(345,30+73,54 \mathrm{ng} / \mathrm{L})$ with the $p$ value $=0,001<p 0,005$. At the ages of 20-30 years, the mean level of HLA-G in the normal pregnant mothers was $357,57+71,40$, while in the abortus groups it was $274,57+85,95$ with the values of $p=0,015$ and the ages of $<20$ and $>35$ years the mean level of HLA-G in the normal pregnant mothers was 306,41+72,26 and in the abortus groups it was $276,79+62,68$ with the value of $p=0,034$. At the pregnancy age of $<14$ week in the normal pregnant mothers, the mean level of $H L A-G=353,43+78.17$ and in the abortus group the mean level HLA-G=243,60+61,77 with the values of $p=0.003$, while at the oage of pregnancy of 8-14weeks the group of the normal pregnant mothers revealed the mean level of $288,71+69,22$ with the value of $p=0,185$. The parity of $2-3$ in normal pregnant mothers revealed the mean of HLA-G $=342,87+73,42$ and in abortus group revealed the mean level of $H L A-G=278,35+81,25$ with the value of $p=0,051$ while the parity 1 and $>3$ in normal pregnant group the maen level of $H L A-G=274,80+84,14$ with the value of $p=0,043$. Therefore, the level of HLA-G serum was lower in the abortus group compared to the normal pregnancy.
\end{abstract}

Key words : HLA-G,abortus, normal pregnancy 


\section{PENDAHULUAN}

Selama kehamilan, wanita dihadapkan pada berbagai komplikasi yang mungkin terjadi, salah satunya adalah abortus.Abortus adalah terganggunya atau keluarnya sebagian atau seluruh hasil konsepsi, yang berakibat pada kematian janin serta ekspulsi dari janin atau embrio tersebut pada usia kehamilan kurang dari 20 minggu atau berat badan janin kurang dari 500 gram [1].

Peristiwa ini adalah komplikasi yang cukup sering terjadi yaitu 15-20\% dari seluruh kehamilan. Sekitar $80 \%$ abortus spontan terjadi pada trimester pertama; insidennya berkurang seiring dengan bertambahnya usia kehamilan. Diperkirakan 4,2juta abortus terjadi setiap tahun di Asia Tenggara, dengan perincian 1,3 juta di Vietnam dan Singapura,antara 750.000 sampai 1,5 juta di Indonesia, 155.000 sampai 750.000 di Filipina dan 300.000 sampai 900.000 di Thailand [2].

Salah satu penyebab abortus adalah kelainan sistem imun dimana kurangnya antibodi yang bekerja untuk melindungi janin dari sistem imun ibu yang akan mengenali genetik ayah sebagai benda asing bagi tubuh sehingga ketika sperma menembus ovum, akan dianggap sebagai benda asing, selain itu sperma dan ovum akan mengekspresikan antigen histocompatability lokus. Fetus merupakan jaringan semiallogenik, separuh dari kromosomnya berasal dari ibu, sedangkan separuh lagi berasal dari ayah.Karena itu ada beberapa kondisi yang harus mendukung, agar fetus dapat ditoleransi dengan baik oleh sistem imun ibu. Salah satu substansi yang penting dalam proses toleransi ibu terhadap fetus adalah Human Leukocyte Antigen-G (HLA-G) [3].

Human Leukocyte Antigen-G (HLA-G) merupakan bagian dari kelompok HLA non klasik kelas Ib. HLA non klasik kelas Ib, terdiri atas HLA-E,G,F. Gen ini terletak di kromosom 6. HLA-G penting bagi pengaturan sistem imun ibu. Hal ini juga diperkuat bahwa pada kondisi pre-eclamsia dan recurrent spontaneous abortus (RSA), HLA-G solubel lebih sedikit dibandingkan kelompok kontrol [3].

HLA-G yang diekspresikan oleh ekstravillous trofoblas (EVT) memainkan peran penting dalam toleransi fetomaternal. HLA-G pada EVT akan terikat pada killer inhibitor receptor (KIR) dan sel natural killer desidua (dNK) dan sel $\mathrm{T}$, sehingga potensi sitotoksisitas terhadap jaringan fetus dihambat oleh ligan dari HLA-G yang terikat pada killer inhibitor receptor (KIR) dari dNK. HLAG dapat melakukan fungsi penghambatan imun melalui 3 jenis reseptor, yaitu ILT2, ILT4, KIR2DL4 [4].

Tujuan umum dari penelitian ini adalah untuk mengetahui kada HLA-G serum pada kehamilan normal dan abortus spontan.Pemeriksaan kadar HLA-G serum dilakukan dengan metode ELISA.

\section{METODE}

Penelitian ini merupakan penelitian observasional analitik menggunakan pendekatan Cross sectional. Penelitian ini dilaksanakan di RSKDIA Sitti Fatimah Makassar Sulawesi Selatan. Populasi dalam penelitian ini adalah semua ibu hamil normal < 20 minggu dan ibu abortus inkomplit yang berkunjung ke poli kandungan RSKDIA Sitti Fatimah Makassar dengan jumlah sampel sebanyak 50 orang yang mana dibagi dalam dua kelompok yaitu 25 sampel kehamilan dengan abortus dan 25 sampel dengan kehamilan normal. Teknik pengambilan sampel yaitu concequtive sampling ,penderita yang memenuhi kriteria inklusi diikutkanpada penelitian ini sampai jumlah sampel terpenuhi. Pengukuran kadar HLAG serum menggunakan metode ELISA.Data diperoleh dari rekam medis dan wawancara langsung pada subjek penelitian menggunakan kuisioner. Untuk menguji data berdistribusi normal/tidak menggunakan uji statistik normalitas.Taraf signifikan $(\alpha=0,05)$. Jika $\alpha>0,05$, maka H0 diterima yaitu data berdistribusi normal. Untuk uji hipotesis menggunakan uji independent T-test, dan uji mann whitney. 


\section{HASIL}

1. Distribusi Karakteristik Subjek Penelitian

Tabel 1 Distribusi Karakteristik Subjek Penelitian

\begin{tabular}{|c|c|c|c|c|c|}
\hline \multirow{2}{*}{ Variabel } & \multicolumn{2}{|c|}{ Hamil Normal } & \multicolumn{2}{|c|}{ Abortus } & \multirow{2}{*}{ P.value } \\
\hline & $\mathbf{n}$ & $\%$ & $\mathbf{n}$ & $\%$ & \\
\hline \multicolumn{6}{|l|}{ Umur ibu } \\
\hline Beresiko $\geq 20-35$ thn & 19 & 76 & 8 & 32 & \multirow{2}{*}{0.005} \\
\hline Risiko Tinggi $<20>35$ thn & 6 & 24 & 17 & 68 & \\
\hline \multicolumn{6}{|l|}{ Umur Kehamilan } \\
\hline$>14$ minggu & 17 & 68 & 7 & 28 & \multirow{2}{*}{0.011} \\
\hline 8-14 minggu & 8 & 32 & 18 & 72 & \\
\hline \multicolumn{6}{|l|}{ Paritas } \\
\hline Berisiko 2-3 & 17 & 68 & 22 & 88 & \multirow{2}{*}{0.048} \\
\hline Risiko Tinggi $1 \&>3$ & 8 & 32 & 18 & 72 & \\
\hline \multicolumn{6}{|l|}{ Riwayat abortus } \\
\hline Tidak ada & 24 & 96 & 9 & 36 & \multirow{2}{*}{0.305} \\
\hline ada & 1 & 4 & 3 & 12 & \\
\hline \multicolumn{6}{|l|}{ Pendidikan } \\
\hline Tinggi & 22 & 88 & 21 & 84 & \multirow{2}{*}{0.500} \\
\hline Rendah & 3 & 12 & 4 & 16 & \\
\hline \multicolumn{6}{|l|}{ Pekerjaan } \\
\hline Bekerja & 9 & 36 & 3 & 12 & \multirow{2}{*}{0.098} \\
\hline Tidak bekerja & 16 & 64 & 22 & 88 & \\
\hline
\end{tabular}

Sumber: Data Primer

Berdasarkan hasil analisis data pada table 1 dari 50 Responden, 25 untuk kehamialn normal dan 25 untuk Abortus. Untuk kategori umur Ibu pada kelompok kehamilan normal terbanyak pada umur 20 tahun - 35 tahun sebanyak 19 (76\%) sedangkaan diagnosa abortus inkomplit yaitu mayoritas pada usia < 20tahun dan > 35 tahun yakni sebanyak 17 (68\%). Hasil uji statistic untuk kategori umur ibu bermaksa signifikan untuk kejadian abortus dimana nilai $p 0,005<(p 0,05)$. Untuk karakteristik umur kehamilan, untuk kelompok kehamilan normal mayoritas umur kehamilan $>14$ minggu sebanyak 17 (68,0 \%) orang sedangkan pada kelompok abortus inkomplit lebih banyak pada umur kehamilan 8-14 mnggu sebanyak 18 (72\%). Hasil uji statistic untuk kategori umur kehamilan bermaksa signifikan untuk kejadian abortus dimana nilai $p 0,011<(p 0,05)$. Untuk karakteristik paritas pada kelompok kehamilan normal terbanyak pada paritas 2-3 sebanyak 17 (68\%) orang sedangkan pada kelompok Abortus terbanyak pada paritas $<1$ dan $>3$ yakni sebanyak $16(64, \%)$ orang. Hasil uji statistic untuk kategori paritas bermaksa signifikan untuk kejadian abortus dimana nilai $p 0,048<(p 0,05)$. Karakteristik pendidikan pada kelompok kehamilan normal terbanyak pada pendidikan tinggi sebanyak 22 (88\%).Hal yang sama pada kelompok abotus terbanyak pada kelompok pendidikan tinggi yakni sebanyak 21 (84\%) orang. Hasil uji statistic untuk kategori pendidikan tidak bermakna untuk kejadian abortus dimana nilai $p 0,500<(p 0,05)$. Selanjutnya untuk karakteristik pekerjaan pada kelompok hamil normal terbanyak pada yang tidak bekerja 16 (64\%) orang dan pada kelompok abortus terbanyak pada yang tidak bekerja sebanyak 22 (88\%) orang. Hasil uji statistic untuk kategori pekerjaan tidak bermakna Antara kelompok hamil normal dan abortus dimana nilai $p 0,095<(p 0,05)$. 
2. Rerata HLA-G Kelompok abortus dan Kelompok hamil normal

Tabel 2 .Perbedaan Rerata HLA-G Kelompok abortus dan Kelompok hamil normal

\begin{tabular}{lllll}
\hline \multicolumn{1}{c}{ Variabel } & \multicolumn{1}{c}{$\mathbf{n}$} & \multicolumn{1}{c}{ Rerata HLA-G } & \multicolumn{1}{c}{ SD } & p \\
\hline Hamil normal & 25 & $345,30 \mathrm{ng} / \mathrm{L}$ & $\pm 73,54$ & \\
\cline { 1 - 4 } Abortus & 25 & $276,08 \mathrm{ng} / \mathrm{L}$ & $\pm 69,10$ & 0,001 \\
\hline
\end{tabular}

Sumber: Data Primer

Dari tabel 2 diperoleh hasil distribusi rerata HLA-G tampak lebih rendah pada abortus (276,08 \pm 69 ng/ L), dibandingkan dengan hamil normal $(345,30 \pm 69,10 \mathrm{ng} / \mathrm{L})$ serta bermakna signifikan dengan nilai $p 0,001<\mathrm{p}$ 0,005 .

3. Rerata Kadar Serum HLAG Pada karakteristik

Tabel 3 :Distribusi Perbedaan Rerata Kadar Serum HLAG Pada karakteristik

\begin{tabular}{|c|c|c|c|c|c|}
\hline \multirow{3}{*}{ Variabel } & \multicolumn{4}{|c|}{ Kelompok penelitian } & \multirow{3}{*}{ P. value } \\
\hline & \multicolumn{2}{|c|}{ Kehamilan normal } & \multicolumn{2}{|r|}{ Abortus } & \\
\hline & $\mathbf{N}$ & $\begin{array}{c}\text { Rerata+SD } \\
\text { (ng/L) }\end{array}$ & $\mathbf{N}$ & $\begin{array}{c}\text { Rerata+SD } \\
\text { (ng/L) }\end{array}$ & \\
\hline \multicolumn{6}{|l|}{ Umur ibu } \\
\hline $\begin{array}{l}\text { Beresiko }(20-35 \\
\text { thn) }\end{array}$ & 19 & $357,57+71,40$ & 8 & $274,57 \pm 85,9$ & 0.015 \\
\hline $\begin{array}{l}\text { Risiko tinggi }(-20 \&> \\
35 \text { tahun }\end{array}$ & 6 & $306,41 \pm 72,26$ & 17 & $276,79 \pm 62,68$ & 0.349 \\
\hline \multicolumn{6}{|l|}{ Umur Kehamilan } \\
\hline$>14$ minggu & 17 & $353,43+78,17$ & 7 & $243,60+61,77$ & 0.003 \\
\hline 8-14 mggu & 8 & $328,01+63,82$ & 18 & $288,71+69,22$ & 0.185 \\
\hline \multicolumn{6}{|l|}{ Paritas } \\
\hline 2-3 "Beresiko" & 17 & $342,87+73,42$ & 9 & $278,35+81,25$ & 0.051 \\
\hline $1 \&>3$ “RISTI" & 8 & $350,46+78,57$ & 16 & $274,80+64,14$ & 0.043 \\
\hline
\end{tabular}

Sumber: Data Primer

Table 3, perbedaan rerata kadar serum HLA-G pada ibu hamil normal dan abortus bermakna $(\mathrm{p}<0,005)$ pada kategori umur ibu beresiko (umur 20-35 thn) dengan nilai p=0,015, umur ibu resiko tinggi < 20 dan $>35$ tahun dengan nilai $p=0,034$, umur kehamilan > 14 minggu dengan nilai p 0,003 dan kategori paritas Resiko tinggi umur< 20 thn \&> 35 thn dengan nilai p=0,043. Hasil analisis Bivariat diperoleh nilai OR=2.000 (OR > 1). Ini berarti bahwa KPD merupakan faktor risiko terhadap persalinan SC dengan risiko 2 kali.

\section{PEMBAHASAN}

Pada penelitian ini, diperiksa kadar HLA-G serum pada ibu abortus dan ibu hamil normal kemudian dilakukan uji statistik, penelitian ini menggunakan uji t independent (SPSS 23.0 for Windows) dan didapatkan nilai p=0,001 (p< 0,05),maka dapat disimpulkan bahwa terdapat perbedaan kadar HLA-G antara abortus dengan kehamilan normal yang signifikan secara statistik dimana kelompok abortus memiliki kadar HLA-G serum yang lebih rendah yakni $276,08 \pm 69$ ng/L dibandingkan dengan kelompok kehamilan normal yakni 345,30 \pm 69,10 ng/L.

Proses implantasi yang berhasil pada manusia tergantung pada sistem pengenalan imun terhadap embrio sejak dini dan respon maternal imun terhadap embrio tersebut. Human Leukocyte Antigen ( HLA-G), suatu HLA kelas I non 
klasik yang berperan penting untuk mengatur sekresi sitokin sebagai pengontrol invasi trofoblas dan mengatur toleransi imun secara lokal.Tingkat Kadar dari HLA-G serum dapat dideteksi pada serum ibu, jaringan plasenta dan darah tali pusat.HLA-G dapat melindungi trofoblas janin dari NK sel lisis ibu dan memberikan toleransi kekebalan janin terhadap ibu. Tingginya kadar HLA-G serum meningkatkan respon Th2 yang berhubungan dengan kehamilan normal. Paparan konsentrasi HLA-G yang tinggi menyebabkan respon dari sitokin Th2 berkembang dan itu penting dalam pemeliharaan kehamilan, sedangkan kadar HLA-G yang rendah dapat meningkatkan ekspresi dari sitokoin Th1 [5].

Salah satu penelitian tentang HLA-G dilakukan oleh Rizzo et al (2009), meneliti perbedaan level soluble HLA-G (sHLA-G) isoform pada plasma maternal kehamilan muda (median 16.4 minggu kehamilan) dan kehamilan tua (median 38.9 minggu kehamilan) dengan studi kohort pada 580 kehamilan wanita Kaukasia. Dari hasil penelitian ini didapatkan konsentrasi sHLA-G1 yang rendah pada kehamilan tua dengan komplikasi dengan kelompok kontrol wanita hamil tanpa komplikasi ( $p=0.029$ pada uji Mann Whitney), dimana disimpulkan bahwa kehamilan dengan komplikasi memiliki kadar HLA-G yang lebih rendah [6].

Menurut Rizzo \& Vercamen (2011), penurunan ekspresi HLA-G pada trofoblas rentan terhadap lisis oleh sel-sel NK desidua dan terjadi kegagalan invasi ke dalam desidua serta arteri spiralis yang berakhir pada gangguan perfusi uteroplasenta sehingga menyebabkan abortus [7].

Selain pada serum kehamilan normal dilakukan juga pemeriksaan kadar HLA-G pada serum abortus dan jaringan plasenta pada subjek yang sama. Hasil uji statisti didapatkan nilai $p=0,000(p<0,05)$ maka dapat disimpulkan bahwa terdapat perbedaan kadar HLA-G pada serum ibu abortus dan jaringan plasenta ibu abortus yang signifikan secara statistic dimana kadar HLA-G pada jaringan plasenta lebih tinggi yaitu 703 $\pm 80 \mathrm{ng} / \mathrm{L}$ sedangkan pada serum abortus 276,08 \pm 69 meskipun pada sampel yang sama. Hal ini dikarenakan Human Leukocyte antigen-G diproduksi pada ekstravilli trofoblas pada plasenta oleh karena itu persentasenya lebih tinggi pada plasenta dibandingkan pada serum.

Temuan pada penelitian ini, kadar HLA-G serum ibu pada kehamilan dengan abortus lebih rendah dari pada kehamilan normal, mungkin di karenakan gangguan toleransi sistem imun maternal dari antigen janin kemudian menyebabkan kadar HLA-G serum tidak optimal atau rendah yang berakibat invasi trofoblas ke desidua tidak adekuat pada saat proses plasentasi sehingga terjadi gangguan remodelling arteri spiralis yang akan menyebabkan perfusi uteroplasenta yang buruk dan akan menyebabkan kematian sel - sel trofoblast.Dengan adanya kematian sel-sel trofoblast maka akan menyebabkan produksi HCG turun. Kondisi ini menyebabkan korpus luteum sebagai penghasil progesteron menjadi tidak terpelihara dan akhirnya menyebabkan progesteron turun. Penurunan progesterone ini berperan penting terhadap proses terjadinya abortus.

Menurut Gonzales (2012), HLA-G berperan penting dalam keberhasilan kehamilan, dan ini dibuktikan dengan rendahnya kadar HLA-G pada kasus abortus dan preeklampsia [8].

Hunt (2009), menyatakan bahwa HLA-G dapat digunakan sebagai marker untuk keberhasilan kehamilan, Dimana kadar HLA-G yang rendah akan sangat meningkatkan risiko terjadinya kegagalan kehamilan [9].

Demikian juga dengan Kresno (2014), yang menyatakan bahwa kadar HLA-G pada kelompok abortus signifikan lebih rendah disbanding pada kehamilan normal [10].

Pada pengamatan kadar HLA-G terlihat juga perbedaan yang signifikan di mana kelompok kehamilan normal dibandingkan dengan kelompok ibu abortus diperoleh nilai pada serum $\mathrm{p}=0,001$ dan jaringan plasenta $\mathrm{p}=0,000$ yang mana lebih kecil dari $\mathrm{p}=0,005$ pada uji independent sampel $\mathrm{T}$-Test ). Dari hasil penelitian ini disimpulkan bahwa walaupun konsentrasi sHLA-G tidak sepenuhnya menentukan keberhasilan kehamilan, tetapi hal ini dapat di pertimbangkan. Beberapa komplikasi kehamilan seperti preeklampsia, arbortus spontan, fetal death, IUGR (intra uterine growth retardtion) dan kelahiran prematur lainnya menunjukkan kadar sHLA-g yang rendah atau bahkan tidak terdapat 
SHLA-G.

\section{KESIMPULAN DAN SARAN}

Kadar HLA-G pada serum ibu abortus lebih rendah dibandingkan pada serum kehamilan normal. Saran untuk penelitian selanjutnya diperlukan sampel yang lebih banyak untuk mendapatkan rerata hasil yang lebih bervariatif, dan karakteristik subyek penelitian dapat dianalisis dengan baik serta perlunya pemeriksaan kadar HLA-G pada jaringan plasenta persalinan normal untukmelihat apakah ada perbedaan kadar HLA-G pada jaringan abortus.

\section{DAFTAR PUSTAKA}

[1] Cunningham.et al., Overview of Obstetrics. Williams Obstetrics, 23rd ed. McGraw-Hill Medical, 2010.

[2] Azhari, Masalah Abortus Dan Kesehatan Reproduksi Perempuan.Bagian Obstetri \& Ginekologi FK UNSRI/ RSMH Palembang. 2012.

[3] Evelyn L. et al., "Peran HLA-G dalam Kehamilan," J. Med., vol. 10, pp. 140-148, 2011.

[4] Chaouat G. et al., Cytokines in pregnancy/early abortion: reexamining the TH1/TH2 paradigm. Int Arch Allergy Immunol, 2011.

[5] Blanco. et al, "Human decidualstromal cellsexpress HLA-G Ef-fects of cytokines and decidualization," vol. 23, 2010.

[6] Rizzo R. at al., "Allergic women have reduced sHLA-G plasma levels at delivery," Am J Reprod Immunol, vol. 61, 2009.

[7] Rizzo R. \& Vercamen M, “The importance of HLAG,HLA-E,HLA-C expression in embryos, trophoblast cells, and embryonic stemcells," vol. 68, 2011.

[8] Gonzalez, "The immunosuppressive molecule HLA-G and its clinical implications," J. Crit. Rev. Clin. Lab. Sci., vol. 49, pp. 63-83, 2012.

[9] Hunt, "Human Leukosit Antigen a human pregnancyrelated immunomodulator," Curr. Opin. Pharmacol., vol. 9, pp. 462-469, 2009.

[10] Kresno, "Kadar human leukocyte antigen-g dan tumor necrosis factor alpha serum ibu pada abortus dan kehamilan normal," J. Kesehat. Reproduksi, 2014 